\title{
PVR wt Allele
}

National Cancer Institute

\section{Source}

National Cancer Institute. PVR wt Allele. NCI Thesaurus. Code C118555.

Human PVR wild-type allele is located in the vicinity of 19q13.2 and is approximately $22 \mathrm{~kb}$ in length. This allele, which encodes poliovirus receptor protein, plays a role in poliovirus adhesion to host cells and the adhesion and activation of natural killer cells. 